\title{
Judgments and Prejudices of Students against Their Failure in the Social Studies Class
}

\author{
Muzaffer Çatak \\ Correspondence: Muzaffer Çatak, Siirt University, Department of Social Science and Turkish Education, Siirt, Turkey.
}

Received: February 11, 2019

doi:10.11114/jets.v7i6.4041

\author{
Accepted: April 17, $2019 \quad$ Online Published: April 22, 2019 \\ URL: https://doi.org/10.11114/jets.v7i6.4041
}

\begin{abstract}
It is necessary to determine the ways of success in order to achieve success. It can be said that it is essential to be aware of the factors that may cause failure to achieve success. Some students have certain prejudices against their classes. This study aims to reveal the prejudice and negative judgments which are thought to affect the failures of students in the social studies class and to establish a solution by determining the prescribed prejudices and judgments that affect students' failures in the relevant class. In addition, as a result of this research, the students who regarded their failure in the social studies class as fundamentally teacher-based indicated it with 138 frequencies in 9 different coding, as self-based with 229 frequencies in 14 different coding and as program-based with 94 frequencies in 4 different coding. It has been seen that the students prioritized themselves more in comparison to the teacher-based and program-based considering the coding varieties and frequency numbers. It can be stated that the students regarded the program as the source of their failure the least.
\end{abstract}

Keywords: social studies, prejudice, cognitive, affective, judgment

\section{Introduction}

Whereas success is a measure of what extent an individual makes benefit of a certain class or academic program in a school setting, success in school can be considered as the average of the grades or scores a student takes in classes (Güleç \& Alkış, 2003). In other words, school success is an indicator determined according to the academic superiority of the student. A school is a place where a setting is prepared for achieving cognitive development, gaining knowledge and attaining academic advantage (Keskin \& Yapıc1, 2008). Many variables affect the academic achievement of a student. These variables are related to physiological, psychological and social situations and circumstances. These learning variables have direct positive or negative effects on the student's achievement level. Student achievement is significantly affected by "non-intellectual" reasons. Among these reasons are the achievement motivation, anxiety, family attributes, socio-economic features, insufficient school and education conditions, general environmental properties and nutritional and health conditions (Güleç \& Alkış, 2003) and the student's personality characteristics, motivation levels and so on (Keskin \& Yapıc1, 2008). Moreover, it was seen that the students, who believed that their achievement or failure was as a result of their behaviors, were more successful and the students, who related their failure with external factors including bad luck, the difficulty of classes, etc., failed in their classes (Döş, 2011).

Academic self-design and achievement are related, and it is essential to define this concept. Academic self-design is defined as the persuasion of the student-developed by him/her about how successful and skillful s/he is about a specific academic pursuit in comparison to other students. In case a student is not able to develop his/her skills adequately in a particular academic study, s/he concludes that s/he is not successful in this field although his/her current success is adequate. This idea is a significant factor that hinders his/her achievement. The research conducted about the relationship between academic self-design and academic achievement illustrates that the most significant factor that affects the child's school success apart from intellectual elements is his/her academic self-design (Arseven, 1986).

Not only the expectations of students but also the expectations of teachers are essential in terms of students' achievements and skills. According to a research, when teachers believe that a student is skillful, they use every means to improve the student's achievement to verify their own decisions and steer the attention to his/her success and enable

\footnotetext{
*This study is a developed and modified form of the report presented at the 6th International Social Studies Education Symposium (the ISSES 6) held during May 4-6, 2017 by Anatolia University.
} 
him/her to attain the expected success. The teachers who reach negative judgments about a student perceive the student's failure rather than his/her success and steer the attention to failure and do not put the required effort to allow the student to progress (Ülgen, 1994).

The recognition of student achievement by teachers affects not only student achievement but also teacher achievement substantially. To ensure that students are recognized by teachers, it is crucial to have an overall awareness of students' attributes such as interests and skills, successes and failures, personal and social adaptation levels, problems, weaknesses and strengths, attitudes and value judgments, and constructive and preventive effects of the environment where they grow up (Olcay \& Döş, 2009). If teachers recognize students thoroughly, their prejudice about student achievement will change, contributing to student achievement positively.

It is also possible to divide the elements that affect the school success of students into in-school and out-of-school. Regarding out-of-school factors, it must be remembered that one of the most crucial factors that are influential on the student's school success is family (Aslanargun \& Özakça, 2015). According to another study, there are many factors that may cause failure in school. These are limited to social, school and bio-psychic factors. Family and friends are seen as key social factors in relation to student failure. The school factor is grouped according to two important approaches.

-How does the teacher teach?

-How is student education and student development in this?

In bio-psychic, it is also noted that the physical and mental development of students should not be overlooked because they cause failure (Roman, 2014).

One of the factors that affect student achievement most is prejudice. Before a detailed explanation of prejudice, it is useful to take a glimpse at the definition of the word prejudice. According to Allport (1979), the word prejudice derives from the Latin word "praejudicium." Many different meanings have been attributed to this word from past to present. This word was used during the ancient times as the 'judgment reached based on the previous decisions and experiences.' During subsequent periods, the meaning of this concept in English was accepted extensively as 'a judgment reached without conducting any necessary research and without consideration.' Again, this concept gained its present meaning when positive and negative sides of it were added to its meaning as 'a judgment formed without any basis and beforehand' (cited by Erdoğan, 2012, 47- 48). According to Allport's opinions as well, the factors on the development of prejudice are (a) learning, (b) conformity, (c) intergroup experiences, (d) identity and status, and (e) developmental stages (Aboud, 2005).

When each failure is properly perceived by the student and considered as a new step for success, failure is not or should not be regarded as a problem. In fact, failure is a new way of learning. People learn about the truth, change their perspective about life, socialize, and find the right thing following mistakes or failures to some extent. However, if students fail to assess their failure and turn it into knowledge and success but take it for granted, then a problem occurs. This problem is the term prejudice.

Though a majority of prejudices against class occur during elementary school, they may also stem from the program, teachers, family or the inner nature and problems of students, etc. The prejudice of students may diminish or escalate during secondary school. Considering this situation in terms of teaching, fighting against the prejudices possessed by students should not be ignored at all (Çatak, Kaya \& Erol, 2016).

It can be assumed that the prejudices accepted by students against success are directly associated with student achievement. These failures will undoubtedly lead to the formation of prejudices about failure. The task of the teachers is to struggle to correct these negativities by determining the reasons and prejudices underlying the failures of the students who have accepted the failure. An important point that should be specifically stated is that in the most recent social studies curricula in Turkey, the skill of "noticing stereotype and prejudice of" skill has been added (MEB, 2018). It is seen in the program that this skill is directly related to an acquisition in the "global connections" theme in the 5th class while it is indirectly related to an acquisition in the "individual and society" theme in the 6th class and an acquisition in the "global connections" theme in the 7th class. Standards are generally directed towards cultural differences and different individuals and groups within the society. However, the lack of cognitive, affective and psychomotor elements related to the student him/herself and education in this program can be regarded as a shortage.

The purpose of this study is to determine the prejudices and judgments that are thought to affect the failures of students in the social studies class. Besides, among the purposes of this study are

1- To determine the differences and similarities related to the failures of students taking part in the sample during the social studies class at the classroom level.

2- To find out the reasons behind the student failure in the social studies class based on the sample. 
3- To compare judgments and prejudices related to the failure of students depending on categories.

4- To provide data to relevant researchers regarding the solution or investigation of the identified problems.

\section{Method}

\subsection{Research Pattern}

In this study, the survey model was used. According to Karakaya (2014), survey researches in social sciences are frequently used and refer to researches which are conducted on large groups and in which individuals 'opinions and attitudes about facts and events are taken and in which facts and events are described. Again, according to Robson (2017), survey researches are a cross-sectional research pattern involving large groups of people and the process of gathering data about several variables. The general purpose of survey research is to present and depict the existing situation related to the research subject (Karasar, 2012; Büyüköztürk, Cakmak, et al., 2014). This study is intended to describe the failure using a cross-sectional study, different variables, and an extensive sample to determine the judgment and prejudices of the students.

\subsection{Study Group}

The research group consisted of four secondary schools selected randomly and affiliated to Siirt Provincial Directorate of National Education during the academic year 2016-2017 and located in the city center. The students in these four secondary schools who enrolled in the 5th, 6th and 7th classes in each secondary school were accessed randomly by using the stratified sampling technique. A total of 487 students attending the 5th, 6th and 7th grades in these secondary schools were reached. A total of 150 students in the fifth grades were reached. Out of these students, 99 of them responded to the form while 51 of them did not respond. One hundred sixty-eight students in the sixth grades were reached. Ninety-four students responded the form and 74 did not respond. One hundred sixty-nine students in the seventh grades were reached, and while 88 of these students responded the form, 81 of them did not respond. Out of a total of 487 students, 281 students responded the form and 206 students did not respond.

\subsection{Data Collection Tool, Data Collection, and Analysis}

An interview form was prepared by the researcher to uncover the prejudices emerging in students' minds against the social studies class and their failure. In this form, students were asked to state five different explanations which were thought to reveal the reasons for their failure in the social studies class. These were:

- I don't have sufficient interest in the social studies class because .....

- I don't study the social studies class. Because.................

- I am not successful in the social studies class. Because...

- I get low grades in the social studies class. Because...........

- Other.

Students were especially informed in the form and class that they could respond to any item in the form and that they did not have to make any clarification for any item if they wished. They were given twenty to thirty minutes to respond based on the classroom environment.

The statement of opinion form was shown to a field teacher before it was applied to students. The required corrections were made based on their statements, and a pilot application was made for two students. The form took its final shape when there were no problems faced.

In this study, the data obtained from the students were analyzed through the content analysis technique. According to Lauri \& Kyngas (2005) content analysis is a method that may be used with either qualitative or quantitative data; additionally, it may be used in an inductive or deductive way (as cited in Elo \& Kyngas, 2008, pp. 109). It is necessary that the data collected in the content analysis should be conceptualized and organized rationally based on the concepts acquired along with the determination of themes (Yıldırım \& Şimşek, 2013). One of the most significant features of the content analysis is digitization, and frequency and percentage are generally used for the interpretation of the data collected through the content analysis (Büyüköztürk et al., 2014).

The significant data obtained from the form were determined, and the classification and coding were made. The relationship between the codes was determined and the data were interpreted using frequencies and percentages. As expressed in the introduction, the coding was initially asked to be evaluated through the teacher and student approach, which was part of the school factor; however, when students examined the responses to the forms, the coding of the program had to be taken into account. Furthermore, grammatically incorrect sentences and slang words observed in a majority part of students' statements were edited by the researcher with literalism and incorporated into the research. 
First, the researcher coded the data indicated by students in the statement of opinion form and then another expert reviewed them. The reliability and relevance between the coding and coders were tested by using the following formula, and the conformity between the coders was examined. It was seen that the expert related 28 opinions included in the codes under different headings.

Reliability $=[\text { Agreement Number / (Agreement }+ \text { Disagreement Number) }]^{*} 100$ (Miles \& Huberman, 1994: 64).

Reliability $=[449 /(449+28)] * 100$

Reliability $=0.9412 \rightarrow 94 \%$

The desired reliability level of $90 \%$ and higher was achieved between the assessments made by the expert and researcher (Saban, 2008).

\section{Results}

In this section, responses given by the $5^{\text {th }}, 6^{\text {th }}$ and $7^{\text {th }}$-grade students were represented in tables and interpreted according to the class order. The last table was created according to the joint explanations given by the $6^{\text {th }}, 7^{\text {th }}$ and $8^{\text {th }}$-grade students. In the last part of the findings, students' opinions supporting the results were included.

Table 1. The Assessment of the $5^{\text {th }}$ Graders by using the Content Analysis Results

\begin{tabular}{|c|c|c|}
\hline THEME & SUB THEME & CODE \\
\hline \multirow[b]{2}{*}{ Teacher-based } & Psychological Attributes & $\begin{array}{l}\text { Nervous }(\mathrm{f}=8) \text {, } \\
\text { Very serious (humorless) }(\mathrm{f}=2) \text {. }\end{array}$ \\
\hline & Pedagogical-Formation Information & $\begin{array}{l}\text { Indifference }(\mathrm{f}=1) \text {, } \\
\text { Inadequate explanation }(\mathrm{f}=19) \text {, } \\
\text { Inadequate knowledge }(\mathrm{f}=9) \text {, } \\
\text { Anti-democratic (classroom environment) }(\mathrm{f}=2) \text {, } \\
\text { Continuous writing ( } \mathrm{f}=10) \text {, } \\
\text { Little activity ( } \mathrm{f}=7) \text {, } \\
\text { Indiscipline }(\mathrm{f}=1) \text {. }\end{array}$ \\
\hline \multirow[t]{3}{*}{ Student-based } & $\begin{array}{l}\text { Psychological and Emotional } \\
\text { Attributes }\end{array}$ & $\begin{array}{l}\text { Excitement }(\mathrm{f}=3) \text {, } \\
\text { Lack of self- confidence }(\mathrm{f}=5) \text {, } \\
\text { Anxious to make a mistake }(\mathrm{f}=5) \text {, } \\
\text { Not listening to the lesson }(\mathrm{f}=7) \text {, } \\
\text { Failure sense }(\mathrm{f}=5) \text {, } \\
\text { Adaptation problem }(\mathrm{f}=2)\end{array}$ \\
\hline & Cognitive Attributes & $\begin{array}{l}\text { Unable to understand }(\mathrm{f}=36) \text {, } \\
\text { Having a short memory }(\mathrm{f}=2) \text {, }\end{array}$ \\
\hline & Other Attributes & $\begin{array}{l}\text { Not studying }(\mathrm{f}=20) \\
\text { Unable to study }(\mathrm{f}=9)\end{array}$ \\
\hline \multirow[b]{2}{*}{ Program-based } & Topic Scope & $\begin{array}{l}\text { Uninteresting topics }(\mathrm{f}=10) \text {, } \\
\text { Confusion between topics }(\mathrm{f}=1) \text {. }\end{array}$ \\
\hline & Content- Student Conformity & $\begin{array}{l}\text { Considering the topics useless }(\mathrm{f}=2) \text {. } \\
\text { Boring }(\mathrm{f}=19) \\
\text { Difficult }(\mathrm{f}=10)\end{array}$ \\
\hline
\end{tabular}


Considering the table in general, it is seen that among the reasons shown by the $5^{\text {th }}$ graders who expressed that the failure in the social studies class was mostly teacher-based were inadequate explanation $(f=9)$, continuous writing $(f=$ $10)$, inadequate knowledge ( $f=9)$ and nervous $(f=8)$. The students who regarded the fundamental reason for their failure as self-based indicated the reasons as unable to understand $(\mathrm{f}=36$ ), not studying $(\mathrm{f}=20)$ and unable to study ( $\mathrm{f}=$ 9). The students who regarded the fundamental reason for their failure in the social studies class indicated the reasons as uninteresting topics ( $\mathrm{f}=10)$, boring topics ( $\mathrm{f}=19)$ and difficult topics $(\mathrm{f}=10)$.

Considering student failure rates within themselves, teacher-based reasons are İnadequate explanation (f=19), 32\%; continuous writing ( $\mathrm{f}=10), 17 \%$; inadequate knowledge $(\mathrm{f}=9), 15 \%$; nervous $(\mathrm{f}=8), 14 \%$; little activity $(\mathrm{f}=7), 12 \%$; very serious personality (humorless) ( $\mathrm{f}=2$ ), $3 \%$; anti-democratic $(\mathrm{f}=2), 3 \%$; undisciplined $(\mathrm{f}=1), 2 \%$; uninteresting $(\mathrm{f}=1), 2 \%$, Student-Based: Unable to understand ( $\mathrm{f}=36$ ), 38\%; not studying ( $\mathrm{f}=20), 21 \%$; unable to study ( $\mathrm{f}=9$ ), $10 \%$; don't listen to the lesson $(\mathrm{f}=7), 8 \%$; lack of self- confidence ( $\mathrm{f}=5), 5 \%$; anxious to make a mistake ( $\mathrm{f}=5), 5 \%$; sense of failure ( $\mathrm{f}=5$ ), $5 \%$; excitement ( $\mathrm{f}=3), 3 \%$; adaptation problem $(\mathrm{f}=2), 2 \%$; quickly forgotten $(\mathrm{f}=2), 2 \%$. Program-Based: Boring ( $\mathrm{f}=19)$, $45 \%$; uninteresting topics ( $\mathrm{f}=10), 24 \%$; difficult $(\mathrm{f}=10), 24 \%$; confusion between topics $(\mathrm{f}=1), 2 \%$; considering the topics useless ( $\mathrm{f}=2), 5 \%$.

Table 2. The Assessment of the $6^{\text {th }}$ Graders by using the Content Analysis Results

\begin{tabular}{|c|c|c|}
\hline THEME & SUB THEME & CODE \\
\hline \multirow[b]{2}{*}{ Teacher-based } & Psychological Attributes & $\begin{array}{l}\text { Nervous }(\mathrm{f}=4) \text {, } \\
\text { Very serious (humorless) }(\mathrm{f}=3 \text { ). }\end{array}$ \\
\hline & Pedagogical-Formation Information & $\begin{array}{l}\text { Indifference }(\mathrm{f}=5) \text {, } \\
\text { Inadequate explanation }(\mathrm{f}=17) \text {, } \\
\text { Inadequate knowledge }(\mathrm{f}=3) \text {, } \\
\text { Continuous writing }(\mathrm{f}=1) \text {, } \\
\text { Indiscipline }(\mathrm{f}=1) \text {. }\end{array}$ \\
\hline \multirow{3}{*}{ Student-based } & Psychological and Emotional Attributes & $\begin{array}{l}\text { Excitement }(\mathrm{f}=4) \text {, } \\
\text { Timidity }(\mathrm{f}=4) \text {, } \\
\text { Lack of self- confidence }(\mathrm{f}=5) \text {, } \\
\text { Not listening to the lesson }(\mathrm{f}=2) \text {, } \\
\text { Adaptation problem }(\mathrm{f}=12) \text {. }\end{array}$ \\
\hline & Cognitive Attributes & $\begin{array}{l}\text { Unable to understand ( } \mathrm{f}=18) \text {, } \\
\text { Having a short memory }(\mathrm{f}=3) \text {, }\end{array}$ \\
\hline & Other Attributes & $\begin{array}{l}\text { Not studying }(\mathrm{f}=16) \\
\text { Unable to study }(\mathrm{f}=8) \\
\text { Illness }(\mathrm{f}=3), \\
\text { Lack of a plan }(\mathrm{f}=2)\end{array}$ \\
\hline \multirow[b]{2}{*}{ Program-based } & Topic Scope & $\begin{array}{l}\text { Uninteresting topics }(\mathrm{f}=5) \\
\text { Confusion between topics }(\mathrm{f}=5) \text {. }\end{array}$ \\
\hline & Content- Student Conformity & $\begin{array}{l}\text { Considering the topics useless }(\mathrm{f}=5) \text {. } \\
\text { Boring ( } \mathrm{f}=26) \text {, } \\
\text { Difficult }(\mathrm{f}=4) \text {, }\end{array}$ \\
\hline
\end{tabular}

It is seen in Table 2 that among the reasons shown by the $6^{\text {th }}$ graders who expressed that the failure in the social studies class was mostly teacher-based were inadequate explanation ( $f=17)$, uninteresting $(f=5)$ and Nervous $(f=4)$. The students who regarded the fundamental reason for their failure as self-based indicated the reasons as unable to understand ( $\mathrm{f}=18)$, not studying $(\mathrm{f}=16)$, adaptation problem $(\mathrm{f}=12)$ and unable to study $(\mathrm{f}=8)$. The students who regarded the fundamental reason for their failure in the social studies class as mostly teacher-based indicated the reasons as boring topics $(\mathrm{f}=26)$, uninteresting topics $(\mathrm{f}=5)$, useless topics $(\mathrm{f}=5)$ and confusion between topics $(\mathrm{f}=5)$.

Considering the student failure rates within themselves, teacher-based reasons are inadequate explanation ( $\mathrm{f}=17), 50 \%$; indifference ( $f=5), 15 \%$; nervous $(f=4), 12 \%$; very serious personality (humorless) ( $f=3$ ), $9 \%$ while student-based reasons are being unable to understand $(\mathrm{f}=18), 23 \%$; not studying $(\mathrm{f}=16), 10 \%$; adaptation problem $(\mathrm{f}=12), 16 \%$; unable to study ( $\mathrm{f}=8), 10 \%$; lack of self- confidence ( $\mathrm{f}=5), 5 \%$; excitement $(\mathrm{f}=4), 5 \%$; timidity ( $\mathrm{f}=4), 5 \%$; quickly forgotten $(\mathrm{f}=3), 4 \%$; illness $(\mathrm{f}=3), 4 \%$; lack of a plan $(\mathrm{f}=2), 3 \%$; not listening to the lesson( $\mathrm{f}=2), 3 \%$; Program-Based: Boring $(\mathrm{f}=26), 47 \%$; uninteresting topics $(\mathrm{f}=5), 9 \%$; confusion between topics $(\mathrm{f}=5), 9 \%$; considering the topics useless $(\mathrm{f}=5)$, $9 \%$; difficult (f=4), $7 \%$. 
Table 3. The Assessment of the $7^{\text {th }}$ Graders by using the Content Analysis Results

\begin{tabular}{|c|c|c|}
\hline THEME & SUB THEME & CODE \\
\hline \multirow[b]{2}{*}{ Teacher-based } & Psychological Attributes & $\begin{array}{l}\text { Nervous }(\mathrm{f}=15) \text {, } \\
\text { Very serious (humorless) }(\mathrm{f}=6) \text {. }\end{array}$ \\
\hline & Pedagogical-Formation Information & $\begin{array}{l}\text { Indifference }(\mathrm{f}=7) \text {, } \\
\text { Inadequate explanation }(\mathrm{f}=11) \text {, } \\
\text { Inadequate knowledge }(\mathrm{f}=2) \text {, } \\
\text { Anti-democratic (classroom environment) }(\mathrm{f}=4) \text {, } \\
\text { Continuous writing ( } \mathrm{f}=3) \text {, } \\
\text { Indiscipline }(\mathrm{f}=1) \text {. }\end{array}$ \\
\hline \multirow{3}{*}{ Student-based } & Psychological and Emotional Attributes & $\begin{array}{l}\text { Excitement }(\mathrm{f}=1) \\
\text { Timidity }(\mathrm{f}=1) \\
\text { Anxious to make a mistake }(\mathrm{f}=6) \\
\text { Not listening to the lesson }(\mathrm{f}=3) \\
\text { Adaptation problem }(\mathrm{f}=8)\end{array}$ \\
\hline & Cognitive Attributes & $\begin{array}{l}\text { Unable to understand }(\mathrm{f}=17) \\
\text { Having a short memory }(\mathrm{f}=2),\end{array}$ \\
\hline & Other Attributes & $\begin{array}{l}\text { Not studying }(\mathrm{f}=12) \\
\text { Unable to study }(\mathrm{f}=3) \\
\text { Play }(\mathrm{f}=1)\end{array}$ \\
\hline \multirow[b]{2}{*}{ Program-based } & Topic Scope & $\begin{array}{l}\text { Uninteresting topics }(\mathrm{f}=3) \text {, } \\
\text { Confusion between topics }(\mathrm{f}=9) \text {. }\end{array}$ \\
\hline & Content- Student Conformity & $\begin{array}{l}\text { Considering the topics useless }(\mathrm{f}=2) \text {. } \\
\text { Boring }(\mathrm{f}=23) \text {, } \\
\text { Difficult }(\mathrm{f}=3) \text {, }\end{array}$ \\
\hline
\end{tabular}

Considering the above-given table in general, it is seen that the reasons stated for the $7^{\text {th }}$ graders' failure in the social studies class were teacher-based the most, and Nervous ( $\mathrm{f}=15$ ) inadequate explanation $(\mathrm{f}=11)$, indifference $(\mathrm{f}=7)$ and very serious $(\mathrm{f}=6)$. The students who regarded the fundamental reason for their failure as self-based indicated the reasons as unable to understand $(\mathrm{f}=17)$, not studying $(\mathrm{f}=12)$, adaptation problem $(\mathrm{f}=8)$ and anxiety to make a mistake $(\mathrm{f}=6)$. The students who regarded the fundamental reason for their failure in the social studies class the most as program-based indicated the reasons as boring topics ( $\mathrm{f}=23)$, uninteresting topics $(\mathrm{f}=5)$ and confusion between topics $(\mathrm{f}=9$ ).

Considering the student failure rates within themselves, the teacher-based reasons are inadequate explanation $(\mathrm{f}=11), \% 22$; continuous writing $(\mathrm{f}=3), 6 \%$; inadequate knowledge $(\mathrm{f}=2), 4 \%$; being nervous $(\mathrm{f}=15), \% 31$; having very serious personality (humorless) $(\mathrm{f}=6), 12 \%$; being anti-democratic $(\mathrm{f}=4), 8 \%$; indiscipline $(\mathrm{f}=1) ; 2 \%$, indifference $(\mathrm{f}=7)$; $12 \%$, while student-based are being unable to understand ( $\mathrm{f}=17), 31 \%$; not studying ( $\mathrm{f}=12), 22 \%$; being unable to study $(\mathrm{f}=3), 6 \%$; failing to listen to the lesson ( $\mathrm{f}=3), 6 \%$; being anxious to make a mistake ( $\mathrm{f}=6), 11 \%$, excitement ( $\mathrm{f}=1), 2 \%$; adaptation problem $(\mathrm{f}=8), 15 \%$; having a short memory $(\mathrm{f}=2), 4 \%$; timidity $(\mathrm{f}=1), 2 \%$; play $(\mathrm{f}=1), 2 \%$, and program-based ones are being boring ( $\mathrm{f}=23), 57 \%$; uninteresting topics $(\mathrm{f}=3), 8 \%$; being difficult $(\mathrm{f}=3), 8 \%$; confusion between topics ( $\mathrm{f}=9$ ), $22 \%$; considering the topics useless $(\mathrm{f}=2), 25 \%$. 
Table 4. The Assessment of the $5^{\text {th }}, 6^{\text {th }}$ and $7^{\text {th }}$ Graders by using the Content Analysis Results

\begin{tabular}{|c|c|c|c|}
\hline THEME & SUB THEME & CODE & GRADES \\
\hline \multirow[b]{2}{*}{ Teacher-based } & Psychological Attributes & $\begin{array}{l}\text { Nervous ( } f=27 \text { ), } \\
\text { Very serious (humorless) }(\mathrm{f}=11) \text {. }\end{array}$ & $\begin{array}{l}(5,6 \& 7 .) \\
(5,6 \& 7 .) \\
\end{array}$ \\
\hline & $\begin{array}{l}\text { Pedagogical-Formation } \\
\text { Information }\end{array}$ & $\begin{array}{l}\text { Indifference }(\mathrm{f}=13) \text {, } \\
\text { Inadequate explanation }(\mathrm{f}=36) \text {, } \\
\text { Inadequate knowledge }(\mathrm{f}=14) \text {, } \\
\text { Anti-democratic (classroom environment) }(\mathrm{f}=6) \text {, } \\
\text { Continuous writing ( } \mathrm{f}=21) \text {, } \\
\text { Little activity }(\mathrm{f}=7) \\
\text { Indiscipline }(\mathrm{f}=3) \text {. }\end{array}$ & $\begin{array}{l}(5,6 \& 7 .) \\
(5,6 \& 7 .) \\
(5,6 \& 7 .) \\
(5 \& 7 .) \\
(5,6 \& 7 .) \\
(5,6 \& 7 .) \\
(5,6 \& 7 .)\end{array}$ \\
\hline \multirow{3}{*}{ Student-based } & $\begin{array}{l}\text { Psychological and Emotional } \\
\text { Attributes }\end{array}$ & $\begin{array}{l}\text { Excitement }(\mathrm{f}=7) \text {, } \\
\text { Timidity }(\mathrm{f}=5) \text {, } \\
\text { Lack of self- confidence }(\mathrm{f}=10) \\
\text { Anxious to make a mistake }(\mathrm{f}=11) \text {, } \\
\text { Not listening to the lesson }(\mathrm{f}=12) \text {, } \\
\text { Sense of failure }(\mathrm{f}=5) \text {, } \\
\text { Adaptation problem }(\mathrm{f}=23) \text {. }\end{array}$ & $\begin{array}{l}(5,6 \& 7 .) \\
(6 \& 7 .) \\
(5,6 \& 7 .) \\
(5,6 \& 7 .) \\
(5,6 \& 7 .) \\
(5) \\
(5,6 \& 7 .)\end{array}$ \\
\hline & Cognitive Attributes & $\begin{array}{l}\text { Unable to understand }(\mathrm{f}=71) \\
\text { Having a short memory }(\mathrm{f}=8)\end{array}$ & $\begin{array}{l}(5,6 \& 7 .) \\
(5,6 \& 7 .) \\
\end{array}$ \\
\hline & Other Attributes & $\begin{array}{l}\text { Not studying }(\mathrm{f}=47), \\
\text { Unable to study }(\mathrm{f}=21) \text {, } \\
\text { Illness }(\mathrm{f}=3) \text {, } \\
\text { Lack of a plan }(\mathrm{f}=2) \text {, } \\
\text { Play }(\mathrm{f}=1) \text {, }\end{array}$ & $\begin{array}{l}(5,6 \& 7 .) \\
(5,6 \& 7 .) \\
(6) \\
(6) \\
(7)\end{array}$ \\
\hline \multirow[b]{2}{*}{ Program-based } & Topic Scope & $\begin{array}{l}\text { Uninteresting topics }(\mathrm{f}=18) \\
\text { Confusion between topics }(\mathrm{f}=5) \text {. }\end{array}$ & $\begin{array}{l}(5,6 \& 7 .) \\
(5,6 \& 7 .) \\
\end{array}$ \\
\hline & Content- Student Conformity & $\begin{array}{l}\text { Considering the topics useless }(\mathrm{f}=9) \text {, } \\
\text { Boring }(\mathrm{f}=36) \text {, } \\
\text { Difficult }(\mathrm{f}=17) \text {, }\end{array}$ & $\begin{array}{l}(5,6 \& 7 .) \\
(5,6 \& 7 .) \\
(5,6 \& 7 .) \\
\end{array}$ \\
\hline
\end{tabular}

In the above table, 22 of the 28 codes are in all classes (5, 6 and 7); 2 code (anti-democracy, timidity) 5,7 and 6,7; 4 code (sense of failure, illness, lack of a plan, play) is seen to be specific to the 5,6,7 classes. It is noteworthy that 22 of 28 codes (about 79\%) are common in all grades. Considering Table 4 on the assessment of the $5^{\text {th }}, 6^{\text {th }}$ and $7^{\text {th }}$ graders about the social studies class and codes with the highest frequency, the frequency of the students who found their failure as teacher-based from the highest to the lowest is as follows: inadequate explanation ( $\mathrm{f}=36$ ), nervous ( $\mathrm{f}=27)$, continuous writing ( $\mathrm{f}=21)$, inadequate knowledge $(\mathrm{f}=14)$, indifference $(\mathrm{f}=13)$, very serious (humorless personality) $(\mathrm{f}=11)$, little activity ( $\mathrm{f}=7$ ), anti-democratic $(\mathrm{f}=6)$, indiscipline $(\mathrm{f}=3)$; the students who regarded the fundamental reason for their failure as self-based indicated the reasons as being unable to understand $(\mathrm{f}=71)$, not studying $(\mathrm{f}=47)$, adaptation problem ( $\mathrm{f}=23$ ), not studying ( $\mathrm{f}=21)$, not listening to the lesson $(\mathrm{f}=21)$, anxiety to make a mistake $(\mathrm{f}=11)$, lack of selfconfidence ( $\mathrm{f}=10$ ), having a short memory $(\mathrm{f}=8)$, excitement $(\mathrm{f}=7)$, timidity $(\mathrm{f}=5)$, sense of failure $(\mathrm{f}=5)$, illness $(\mathrm{f}=3$ ), lack of a plan ( $\mathrm{f}=2)$, and play $(\mathrm{f}=1)$; the students who regarded the fundamental reason for their failure in the social studies class as mostly program-based indicated the reasons as boring topics $(\mathrm{f}=36)$, uninteresting topics $(\mathrm{f}=18)$, being difficult ( $\mathrm{f}=17$ ), confusion between topics ( $\mathrm{f}=15)$ and useless topics $(\mathrm{f}=9)$.

Considering the student failure rates within themselves, teacher-based reasons are inadequate explanation ( $\mathrm{f}=36$ ), 26\%; being nervous ( $\mathrm{f}=27), 20 \%$; continuous writing $(\mathrm{f}=21), 15 \%$; inadequate knowledge $(\mathrm{f}=14), 10 \%$; indifference ( $\mathrm{f}=13$ ), $9 \%$; having a very serious personality (humorless) ( $\mathrm{f}=11), 8 \%$; being anti-democratic $(\mathrm{f}=6), 4 \%$; indiscipline ( $\mathrm{f}=3), 1 \%$. On the other hand, while student-based reasons are being unable to understand ( $\mathrm{f}=71), 31 \%$; not studying ( $\mathrm{f}=47$ ), 20\%; not listening to the lesson ( $\mathrm{f}=12), 5 \%$; being anxious to make a mistake ( $\mathrm{f}=11) ; 5 \%$, lack of self- confidence ( $\mathrm{f}=10), 4 \%$; having a short memory $(\mathrm{f}=8), 3 \%$; excitement $(\mathrm{f}=7), 3 \%$; timidity $(\mathrm{f}=7), 3 \%$; sense of failure $(\mathrm{f}=5), 3 \%$; illness $(\mathrm{f}=3)$, $2 \%$; lack of a plan $(\mathrm{f}=2), 1 \%$; play $(\mathrm{f}=1), 0.5 \%$ while program-based ones are being boring $(\mathrm{f}=36), 38 \%$; uninteresting topics ( $\mathrm{f}=18), 19 \%$; being difficult $(\mathrm{f}=17), 18 \%$; confusion between topics $(\mathrm{f}=15), 16 \%$; considering the topics useless $(\mathrm{f}=9), 9 \%$. 


\subsection{Extracts from the Opinions of Students}

Nervous: "My teacher is furious. I am sometimes afraid of asking questions." Adaptation problem: "I cannot focus on the class," "I get distracted very easily. I cannot focus." The sense of failure: "I always get low grades in the social studies class." Inadequate explanation: "My teacher talks very fast. I don't understand anything”. Not studying: "I don't feel like studying.", "I don't want it. I don't like studying at all.", "I don't ever review my lessons." Unable to study: "My father takes me to his work. I cannot study", "My mother makes me do housework. She doesn't want me to study", "I babysit. I cannot study." Indiscipline: "Our class is very naughty. It is impossible for me to succeed.” Play: "I cannot study because I play." Little activity: "I am not successful in this class because my teacher does not let us do enough activity," "We rarely do activities." Illness: "I am unable to recover from illness. I am always ill." Anti-democratic (class setting): "My teacher rules the class. She doesn't care about what we want." Difficult: "The class is tough for me," "It is both difficult and boring" Continuously writing: "My teacher makes us write all the time. There is always writing and writing," "My fingers hurt from writing all the time. My teacher makes us write all the time." Indifference: "My teacher doesn't pay attention to me," "My teacher doesn't let me speak." Confusion between topics: "It is a very complicated class. It is history and then geography", "The topics are very complex." Lack of a plan: "I don't have a plan, and I think that my class is affected by it." Unable to understand the class: "I don't understand this class absolutely," "I don't want to understand." Boring: "It is a very boring class," "The topics are very boring."

\section{Discussion}

In conclusion, in this research, the students who regarded their failure in the social studies class as teacher-based fundamentally indicated it with 138 frequencies in 9 different coding, and those who regarded it as self-based indicated it with 229 frequencies in 14 different coding, and those who regarded it as program-based indicated it with 94 frequencies in 4 different coding. It is seen that the students prioritized themselves more in comparison to the teacher-based and program-based considering the coding varieties and frequency numbers. It can be stated that the students regarded the program as the source of their failure the least. These data show us a very significant detail. The students in this study indicated themselves as the greatest reason for their failure and as a result, it is revealed that the students are close to achievement and need to be supported. These data can also be regarded as a student call for help from educators.

When the sub-theme is evaluated, it is observed in the teacher-based theme that the frequency of the pedagogic formation information was high while the rate of cognitive attributes was high in the student-based theme, and the frequency of the content and student adaptation was high in the program-based theme. On the contrary, the sub-themes with the least frequency were the psychological attributes of the teachers in the teacher-based theme, while it was the psychological and affective attributes of the students in the student-based theme and student content adaptation in the program-based theme.

It was observed in a survey conducted by Kara \& Kutay (2016) through a poll carried out with students to determine the negative behavior of male and female teachers, the unfair penalty of teachers and discrimination were associated with the code of (anti-democratic class environment), flying into a temper and getting angry intemperately with the code of (Nervous), insufficient lecturing by female teachers or failing to lecture with the code of (insufficient lecturing, inadequate knowledge), and continuously writing on the board with the code of (continuous writing).

It was determined in the study conducted by Aslan \& Doğu (2015) that students do not enjoy texts which are informative, long and irrelevant, have challenging activities and dwell on the same subject while they had fun in reading entertaining and funny texts. Besides, researchers have reported that books should be structured with texts which are related to the experiences of students, sensitive to their age, developmental characteristics, interests, needs, and skills, and appropriate to their level of restructuring. In the study of Kurtuluş \& Çavdar (2015), the opinions of teachers were received on the activities carried out in the science and technology class curriculum. Some of these opinions related to the curriculum were stated as "engaging," "suitability for student level," "entertaining," "simple", "convenient learning", and "remarkable." On the other hand, students shared their opinions as "convenient learning," "simple," "entertaining," "remarkable" and "engaging" on class activities. The stated opinions suggest that we need to take advantage of class activities more efficiently to minimize the program-based problems in this study.

In their study conducted to assess student opinions according to the reasons of absenteeism, Sanl, Altun \& Tan (2015) stated that schools should be taken out of the classroom environment and made more environmentally friendly and social for the students. As a result of the study conducted with 526 students by Duman, Gelişli \& Çetin (2004), students stated that teachers adopt an interventionist-oppressive approach rather than a modern-constructive approach. This study overlaps with their study as in both studies it is stated that there is an antidemocratic class environment ( $\mathrm{f}=6$ ) with nervous $(\mathrm{f}=27)$ and very serious $(\mathrm{f}=11)$ teachers. 
As seen above, it is stated in the study that students are hesitant and uncommitted ( $\mathrm{f}=12$ ). In the study conducted by Seyhan (2017), a student expressed that students should be given responsibility to overcome excitement by stating "I feel comfortable in my performance homework, but in my exam, everything slips my mind due to overexcitement...". Besides, Altınbaşak (2008) stated that increasing cooperation between countries in the field of academic, commercial and tourism will help prevent prejudice.

In the study conducted by Tatllı̆ıglu \& Korkmaz (2015) with 272 middle school students, among the causes of failure were the items "I do not have a separate study room", "I'm learning in the classroom, but I immediately forget", "I can't pay attention to my lessons constantly". Eight students in this study also pointed out that they quickly forget what they have learned in the class while twenty-three of them stated that they are unable to adapt to the class. Teacher indifference ( $\mathrm{f}=13$ ) was found to affect the student's success in the study.

Celikkaya \& Seyhan (2016), in their study with 50 students from 8th grade, stated that students should be valued based on the statements under the theme of valuing students as "valuing humans does not matter either materially or spiritually. It is not only about valuing but also making this value be felt" and "It is mutual value to one another." If the teacher is indifferent, opposite emotions will emerge.

Tuncer \& Bahadir (2017), in their study on 214 students, found that students who describe themselves as "unsuccessful" and who are "double-minded" in terms of their success mainly center upon the statement as "I want to go as far as I can go." Furthermore, among the two main results of failure determined in this study were, shown in the statements as "I cannot succeed because of my brothers" and "I cannot succeed because I have health problems". In this study, three out of 281 students stated that they failed due to illness.

\section{References}

Aboud, F. E. (2005). On the nature of prejudice fifty years after Allport. Dovidio J. F., Glick P. and Rudman L. A. (Ed.). The Development of Prejudice in Childhood and Adolescence (pp.310-327). USA, BlackwellPublishing. http://en.bookfi.net/book/1249730. 03.04.2019

Altınbaşak, İ. (2008). Understanding the prejudices in order to improve the image of Turkey: A qualitative study on the prejudices of Italians about Turkey. Boğaziçi Journal, 22(1-2), 35-51. https://doi.org/10.21773/boun.22.1.3

Arseven, A. (1986). The effect of the family on the development of self-esteem in children and the success of the child at school. Education and Science, 10(60), 11-17.

Aslan, C., \& Doğu, Y. (2015). The students ' vision of the texts in the Turkish textbooks of the middle school. Journal of Academic Studies, 17(67), 1-29.

Aslanargun, E., \& Özakça, B. (2015). The participants of their families to contribute to the success of students who are higher in their academic achievements. Anadolu University Journal of Social Sciences, 15(3), 9-21.

Büyüköztürk, Ş., Çakmak, E. K., Akgün, Ö. E., Karadeniz, Ş., \& Demirel, F. (2014). Scientific research methods. (18. edition). Ankara: Pegem.

Çatak M., Kaya M. F., \& Erol H. (2016). Affective prejudices for students ' social studies course. USBESV 2016, 438-449. (full text), (edition no:2926661)

Çelikkaya, T., \& Seyhan, O. (2016). Effective factors in the acquisition of values (student opinions). Balikesir University Journal of Social Sciences Institute, 19(36), 167-191.

Döş, İ. (2011). Teachers ' opinions on the reasons for failure of secondary school students. National Education, (190), $72-91$.

Duman, T., Gelişli, Y., \& Çetin, Ş. (2004). The opinions of high school students about teachers' approach to discipline in the classroom. Turkish Journal of Educational Sciences, 2(3), 281-292. Retrieved from http://dergipark.gov.tr/tebd/issue/26127/275212

Elo, S., \& Kyngas, H. (2008). The qualitative content analysis process. Journal of Advanced Nursing, 62(1), 107-115. https://doi.org/10.1111/j.1365-2648.2007.04569.x

Erdoğan, Ç. (2012). Relationship with trust culture and prejudice in elementary school schools. (Unpublished doctoral dissertation). Ankara University Institute of Educational Sciences, Ankara.

Güleç, S., \& Alkış, S. (2003). The primary level of elementary school students ' relationship with each other in the courses. Elementary School Online, 2(2).

Kara, M., \& Kutay, F. (2016). The negative words and behaviors of middle school teachers in terms of the language-behavioral relationship. Education in the 21st Century and Society of Educational Sciences and Social 
Research Journal, 5(15), 315-332.

Karakaya, İ. (2014). Scientific research methods. A. Tanrı̈ğen (ed.), Scientific research methods. (pp.191-248) Ankara: An1.

Karasar, N. (2012). Scientific research method concepts-principles-techniques (23. edition), Ankara: Nobel.

Keskin, H. K., \& Yapıcı, Ş. (2008). Teachers and parents' opinions on the personality traits of successful and unsuccessful students. Kocatepe University Journal of Theoretical Educational Science, Afyon, 1(1), 20-32.

Kurtuluş, N., \& Çavdar, O. (2015). A teacher and student thinking about the activities in the Science and technology teaching program. Necatibey Faculty of Education, Electronic Science and Mathematics Training Journal, 5(1), 1-23. Retrieved from http://dergipark.gov.tr/balikesirnef/issue/3372/46533

MEB, (2018). Social studies course curriculum (primary and secondary school 4, 5, 6 and 7. classes) http://mufredat.meb.gov.tr/Dosyalar/201812103847686-SOSYAL\%20B\%C4\%B0LG\%C4\%B0LER\%20\%C3\%96 \%C4\%9ERET\%C4\%B0M\%20PROGRAMI\%20.pdf

Miles, M. B., \& Huberman, A. M. (1994). Qualitative data analysis: an expanded source book. (2. edition), London: Sage Publications

Olcay, A., \& Döş, İ. (2009). An application for determining the student dimension of the elements that negatively affect success in secondary education. Gaziantep University Journal of Social Sciences, 8(1), 131-155.

Robson, C. (2017). Scientific research methods real world research. (Ş. Çınkır \& N. Demirkasımoğlu, trans. edit.), (2. edition), Ankara: Anı.

Roman, M. D. (2014). Students' failure in academic environment. Procedia - Social and Behavioral Sciences, 114, 170177. https://doi.org/10.1016/j.sbspro.2013.12.679

Saban, A. (2008). Metaphors for school. Theory and Practice Educational Management Journal, 55, 459-496.

Şanlı Ö., Altun, M., \& Tan, Ç. (2015). Examining the reasons for students being absent from schools in accordance with the views of the students who are absent from their schools. Electronic journal of Social Sciences, 14(55), 161-177.

Seyhan, A. (2017). Their views on the performance tasks of secondary school students. Electronic Journal of Social Sciences, 16(60), 60-75. https://doi.org/10.17755/esosder.289651

Tatlılığlu, K., \& Korkmaz, G. (2015). A study aimed at defining the reasons that effect the school success of the primary school students negatively (the sample of konya). Cankiri Karatekin University Journal of Faculty of Letters, 6(6), 93-116.

Tuncer, M., \& Bahadır, F. (2017). Reasons for underachievement by secondary schools students opinions. Kahramanmaras Sutcu Imam University Education Journal, 1(1), 1-11. Retrieved from http://dergipark.gov.tr/ksued/issue/32916/368156

Ülgen, G. (1994). Is the expectation of success important? Education and Science, 18(92), 21-24. https://doi.org/10.1007/BF02356325

Yıldırım, A., \& Şimşek, H. (2013). Research methods in social sciences (9. edition). Ankara: Seckin.

\section{Copyrights}

Copyright for this article is retained by the author(s), with first publication rights granted to the journal.

This is an open-access article distributed under the terms and conditions of the Creative Commons Attribution license which permits unrestricted use, distribution, and reproduction in any medium, provided the original work is properly cited. 